\title{
Efektivitas seduhan kayu manis (Cinnammon Burmanni) dan jahe merah (Zingeber Offcinale) terhadap penurunan GDS pada pasien DM tipe 2
}

\author{
Effectiveness of steeping cinnamon (Cinnamon Burmanni) and \\ red ginger (Zingiber Officinale) on blood glucose levels in \\ patients with type 2 diabetes mellitus \\ Iyar Siswandi ${ }^{1, *}$, Yani Sofiani ${ }^{2}$, Diana Irawati \\ ${ }^{1,2,3}$ Universitas Muhammadiyah Jakarta, Jalan K. H. Ahmad Dahlan Cirendeu Ciputat Jakarta 15419, Indonesia \\ 1iyarsiswandi24@gmail.com* \\ * corresponding author
}

Tanggal Submisi: 25 Agustus 2019, Tanggal Penerimaan: 27 Agustus 2019

\begin{abstract}
Abstrak
Hipergelikemia merupakan salah satu permasalahan pasien Diabetes Melitus akibat kekurangan sereksi insulin, dapat diatasi menggunakan kayu manis (Cinnammon Burmanni) dan jahe merah (Zingeber Offcinale). Penelitian bertujuan untuk mengetahui efektifitas pemberian seduhan kayu manis (Cinnammon Burmanni) dan jahe merah (Zingeber Offcinale) terhadap kadar glukosa darah. Desain penelitian digunakan adalah quasi eksperimen pre dan post two group. Dengan sampel adalah 24 sampel dibagi 2 kelompok, menggunakan teknik simpel random sampling dengan uji Dependen di dapatkan hasil ada pengaruh kedua kelompok terhadap kadar glukosa darah dan dilihat selisih kelompok kayu manis memiliki selisih rata-rata kadar glukosa darah lebih tinggi dari pada jahe merah.
\end{abstract}

Kata Kunci : kayu manis (cinnamon); jahe merah (zingiber officinale); diabetes melitus tipe 2; kadar gula darah

\begin{abstract}
Hyperglycemia is one of the problems caused by Diabetes Mellitus patients insulin deficiency, can be overcome using cinnamon and red ginger. The research aims to determine the effectiveness administration of cinnamon steeping and red ginger against blood glucose levels. The research design used was quasi pre and post two group. With a sample of 24 samples divided into 2 group, using tecniques simple random sampling with the dependent test results in a second effect group against blood glucose levels and judging by the difference the cinnamon group had the average difference in blood glucose levels is higher than red ginger.
\end{abstract}

Keywords: cinnamon (cinnamon); red ginger (zingiber officinale); type 2 diabetes mellitus; blood sugar levels. 


\section{PENDAHULUAN}

Diabetes Melitus merupakan penyakit metabolik yang sistemik dan kronis yang ditandai dengan tingginya kadar glukosa darah (hyperglikemia) sebagai akibat dari kekurangan sekresi insulin (ADA, 2014). Diabetes Melitus pada umumnya merupakan kategori penyakit tidak menular yang menjadi masalah kesehatan masyarakat, baik secara global, regional, nasional maupun lokal dan penyakit metabolik yang selalu mengalami peningkatan pasien setiap tahun dinegara-negara seluruh dunia (Sarwono, 2014).

Berdasarkan estimasi Internasional Diabetes Federation (IDF) tahun 2018 terdapat lebih dari 371 juta orang hidup dengan diabetes di dunia pada tahun 2018 dan diperkirakan 371 juta orang, 175 juta diantaranya belum terdiagnosis, sehingga terancam berkembang progesif menjadi komplikasi tanpa disadari dan tanpa pencegahan. Pada tahun 2025 jumlah tersebut diperkirakan akan meningkat menjadi 592 juta orang dan diperkirakan pada tahun 2025 di Indonesia akan menduduki peringkat ke 3 pasien Diabetes Melitus terbesar di dunia (Internasional Diabetes Federation, 2018). Berdasarkan hasil Riskesdas (2018) peningkatan terjadi dari tahun 2013 sebanyak 6,9\% menjadi 10,9\% meningkat pada tahun 2018 menjadi 2,1\% dari 250 juta orang di Indonesia di bawah China, India, Brazil, Rusia dan Mexico. Angka kejadian penyakit Diabetes Melitus di Provinsi NTB mencapai 98.042 kasus. Jumlah pasien Diabetes Melitus tertinggi sebanyak 4.986 jiwa di Kabupaten Sumbawa (Profil Kesehatan NTB, 2017). Sedangkan angka Diabetes Melitus tipe 2 di Puskesmas Tarano 47 jiwa tahun 2017 dan meningkat menjadi 61 jiwa 2018 (Dinkes Kab. Sumbawa 2018). Angka kejadian Diabetes Melitus di masyarakat setiap tahun terjadi peningkatan, dan membutuhkan pengobatan secara tepat pada pasien (Sarwono, 2014).

Penatalaksanaan yang tepat akan memperlambat timbulnya komplikasi sedini mungkin. Permasalahan yang paling banyak ditemukan pada pasien Diabates Melitus dengan kadar glukosa darah yang $>120 \mathrm{mg} / \mathrm{dl}$ (PERKENI, 2015). Diperlukan pengendalian yang tepat untuk menghindari terjadinya komplikasi pada Diabates Melitus dengan berbagai macam komplikasi yang akan menyerang seluruh tubuh pasien Diabates Melitus (Apriyanti, 2015). Umumnya 80\% pasien diabetes menyadari bahwa mereka menderita diabetes, dan hanya $20 \%$ dari pasien melakukan pemeriksaan kadar glukosa darah secara teratur, untuk itu kontrol kadar gula darah bagi pasien Diabetes Melitus sangat penting karena dapat membantu menetukan penanganan medis yang tepat sehingga menggurangi resiko komplikasi yang berat dan membantu pasien menyesuaikan atau mengatur pola makanan, aktivitas fisik dan kebutuhan kadar insulin untuk memperbaiki kadar glukosa darah sehari-hari (Apriyanti, 2015).

Penatalaksanaan dan cara mengontrol kadar glukosa darah membutuhkan penangganan multidisiplin yang meliputi terapi farmakologi dan non-farmakologi, terapi farmakologi yang diberikan yaitu Obat Hipolgikemik Oral (OHO) dan terapi insulin, selain obat tersebut perlu dikontrol juga pengaturan diet, olahraga, edukasi sehingga glukosa darah normal (Agoes, 2015). Kelemahan atau keterbatasan yang muncul pada pasien Diabetes Melitus yang mendapatkan terapi farmakologi karena keterbatasan obat, efek samping obat dan jarak pelayanan kesehatan yang tidak terjangkau dari tempat tinggal, untuk mengatasi permasalahan tersebut, saat ini mulai dikembangkan terapi non farmakologi (Agoes, 2015). Para ahli mengembangkan pengobatan secara terapi non-farmakologi sangat penting juga bagi pasien Diabetes Melitus, salah satunya adalah terapi herbal (Suyono, 2014).

Penggunaan obat herbal dari jenis rempah-rempah telah banyak digunakan untuk mengatasi berbagai penyakit seperti Diabetes Melitus. Herbal jenis rempah-rempah 
yang digunakan oleh masyarakat secara empirik antara lain adalah bawang putih (Allium Sativum Linn), kunyit (Curcuma domestica), kayu manis (Cinnamon burmanni), jahe merah (Zingiber officinale), daun salam (Syzygium polyanthum), dan cengkai (Syzygium aromaticum), seperti diungkapkan oleh Sulistiyani (2015) dengan judul pengaruh pemberian terapi kunyit, dan bawang putih terhadap penurunan kadar glukosa darah pada pasien Diabetes Melitus di Semarang dengan jumlah responden 30 di dapatkan hasil bahwa kunyit dan bawang putih dapat menurunkan kadar glukosa darah pada pasien Diabetes Melitus dalam jumlah yang sedikit karena mengandung allicin dan kurkumin yang memproduksi hormon insulin dalam tubuh dibandingkan dengan olahraga pada pasien diabetes sedangkan kayu manis dan jahe merah mampu menurunkan kadar glukosa darah mendekati normal (Smeltzer, et al, 2014).

Kayu manis dan jahe merah biasa digunakan pada bahan rempah-rempah pada masakan. Kayu manis memiliki aroma manis yang wangi, bersifat hangat, rasa yang pedas, tetapi sedikit manis. Kayu manis mengandung minyak esensial, seperti eugenol dan polifenol yang membantu peningkatan protein reseptor insulin pada sel, sehingga dapat meningkatkan sensitivitas insulin dan menurunkan kadar glukosa mendekati normal (Farry, 2014). Mengkomsumsi 1 gram kayu manis per hari dapat meningkatkan sensitivitas insulin- hormon pengatur glukosa darah sehingga bisa membantu pengobatan Diabetes Melitus. Hal ini didukung dengan penelitian yang dilakukan oleh Bobby A, (2015) dengan judul pengaruh pemberian sediaan ekstrak kayu manis (Cinnamommun burmanii) terhadap kadar glukosa darah pada pasien Diabetes Melitus tipe 2, di Semarang dengan jumlah 46 responden didapatkan hasil bahwa ada pengaruh pemberian ekstrak kayu manis terhadap kadar glukosa darah setelah diberikan intervensi berupa seduhan bubuk kayu manis dalam dosis 10 gram dengan hasil yang signifikan.

Sedangkan jahe merah mengandung minyak astiri dan gingerol yang mampu meningkatkan penyerapan glukosa darah kedalam sel otot dan jahe merah membantu mengontrol kadar glukosa darah pada pasien Diabetes Melitus untuk mencegah komplikasi jangka panjang (Rismunandar, 2015). Hal ini didukung dengan penelitian yang dilakukan oleh Arman Eliza, (2016) dengan judul pengaruh pemberian serbuk kering jahe merah terhadap pasien Diabetes Melitus tipe 2, di Padang Sumatra Barat dengan jumlah 33 responden didapatkan hasil bahwa ada pengaruh yang signifikan terhadap pemberian terapi jahe merah terhadap kadar glukosa darah pada pasien Diabetes Melitus tipe 2.

\section{METODE PENELITIAN}

Desain yang di gunakan pada penelitian ini Quasi eksperimen pre dan post two group yaitu kedua kelompok dilakukan intervensi sesuai dengan metode yang kehendaki (Nursalam, 2015). Pada desain ini terdapat dua kelompok yaitu kelompok kayu manis dan jahe merah. Populasi dalam penelitian ini adalah semua pasien Diabetes Melitus tipe 2 yang pernah berobat di Puskesmas Tarano Kabupaten Sumbawa NTB sebanyak 61 orang. Jumlah sampel dalam penelitian ini dengan menggunakan rumus Slovin adalah 24 reponden, yang terdiri dari 12 kelompok kayu manis dan 12 kelompok jahe merah.

Penelitian ini dilakukan setelah mendapat persetujuan dari dewan peninjauan etika atau telah lolos kaji etik di Universitas Muhammadiyah Jakarta. Peneliti telah menjelaskan tentang penelitian ini kepada para calon responden termasuk tujuan, metode, manfaat dan risikonya. Peneliti menjamin kerahasiaan para peserta dan memberikan hak kepada responden bahwa mereka dapat menarik diri dari penelitian 
kapanpun tanpa implikasi untuk perlakuan selanjutnya. Statistik deskriptif dilakukan untuk mengetahui gambaran karakteristik sampel dan pengukuruan darah. Paired t test dilakukan untuk melihat perbedaan kadar glukosa darah sebelum dan setelah pemberian seduhan kayu manis dan jahe merah serta membuktikan hipotesis penelitian. Data yang telah terkumpul diolah dengan menggunakan aplikasi SPSS versi 22. Sebelum uji bivariat, sudah dilakukan uji normalitas data dengan menggunakan uji Shapiro-Wilk. Uji normalitas dilakukan pada kadar glukosa darah masing-masing kelompok perlakaun. Sehingga di dapatkan $p$ value $>0,05$ yang berarti data berdistribusi normal. selanjutnya di lakukan Uji Paired t test.

\section{HASIL DAN PEMBAHASAN}

Efektivitas seduhan kayu manis (Cinnammon Burmanni) dan jahe merah (Zingeber Offcinale) terhadap penurunan GDS pada pasien DM tipe 2 di peroleh data Distribusi Responden Berdasarkan Usia dan pola makan pada pasien Diabetes Melitus Di Puskesmas Tarano Kabupaten Sumbawa NTB Februari-Maret 2019 (n=24) di sajikan dalam tabel 1 .

Tabel 1. Distribusi responden berdasarkan usia dan pola makan pada pasien diabetes melitus di Puskesmas Tarano Kabupaten Sumbawa NTB Februari-Maret 2019 (n=24)

\begin{tabular}{|c|c|c|c|c|c|c|}
\hline \multirow[b]{2}{*}{ Variabel } & \multicolumn{3}{|c|}{ Kayu manis $(n=12)$} & \multicolumn{3}{|c|}{ Jahe merah $(n=12)$} \\
\hline & $\begin{array}{l}\text { Mean } \pm \text { SD } \\
(\text { min-maks) }\end{array}$ & F (\%) & CI 95\% & $\begin{array}{l}\text { Mean } \pm \text { SD } \\
(\text { min-maks })\end{array}$ & F (\%) & CI $95 \%$ \\
\hline Usia & $\begin{array}{c}62.83 \pm 7.13 \\
(52-76)\end{array}$ & & $58.30-67.37$ & $\begin{array}{c}55.42 \pm 11.64 \\
(36-70)\end{array}$ & & $\begin{array}{l}47.99- \\
62.84\end{array}$ \\
\hline \multicolumn{7}{|l|}{ Pola makan } \\
\hline Baik & & $10(83.3)$ & & & $10(83.3)$ & \\
\hline Kurang baik & & $2(16.7)$ & & & $2(16.7)$ & \\
\hline
\end{tabular}

Sumber : Data primer, 2019

Berdasarkan tabel 1 menunjukan bahwa karakteristik rata-rata usia responden lebih tinggi pada kelompok kayu manis dibandingkan kelompok jahe merah sedangkan dilihat dari pola makan pada kedua kelompok memiliki nilai yang sama atau setara baik pada kedua kelompok. Data karateristik responden yang diperoleh dari penelitian ini dimulai dari usia. Usia merupakan salah satu faktor yang mempengaruhi tingkat kejadian Diabetes Melitus. Rentang usia dalam penelitian ini adalah 36 sampai dengan $>66$ tahun.

Kejadian dan prevalensi pasien Diabetes Melitus meningkat seiring dengan bertambahnya usia (Deshpande, Hayes \& Schootman, 2012). Hal ini dikarenakan adanya penurunan fungsi tubuh seiring dengan bertambahnya usia seseorang dan terjadinya penurunan sensitivitas reseptor insulin, penurunan regulasi hormon glukagon dan efineprin yang pada akhirnya mempengaruhi kadar glukosa darah (Black \& Hawks, 2016).

Menurut ADA (2012) seseorang yang paling sering menderita diabetes antara berumur 36 sampai $>64$ tahun, pada rentang tersebut dikaitkan dengan berbagai macam penyakit degenerative yang salah satunya adalah Diabetes Melitus. Seiring bertambahnya usia, tubuh mempunyai daya toleransi yang rendah terhadap glukosa, dimana kondisi ini disebabkan karena perubahan reseptor glikoprotein yang akan membantu insulin mentransfer glukosa kedalam sel-sel otot, hepar, dan jaringan adipose 
mengalami penurunan sehingga timbul defesiensi reseptor terhadap insulin, dan sekresi insulin tidak menurun dengan bertambahnya usia, tetapi kepekaan reseptor yang berinteraksi dengan insulin mengalami penurunan (Fredy, 2014).

Penelitian ini sejalan dengan temuan penelitian yang pernah dilakukan oleh Wulandari, (2015) yaitu distribusi usia responden dengan Diabetes Melitus paling banyak ditemukan pada rentang 45-64 tahun. Peningkatan usia dapat menyebabkan resiko terkena Diabetes Melitus karena terjadi peningkatan intoleransi glukosa, seiring dengan adanya proses penuaan (aging proses) yang mempengaruhi kemampuan sel pankreas dalam memproduksi insulin, selain itu pada individu yang yang lebih tua akan terjadi penurunan aktivitas mitokondria yang akan menyebabkan peningkatan kadar lemak yang akan memicu terjadinya resistensi insulin (Sujaya, 2013). Teori yang ada mengatakan bahwa seseorang $\geq 45$ tahun memiliki peningkatan resiko terhadap terjadinya Diabtes Melitus dan intoleransi glukosa yang di sebabkan oleh faktor degeneratif yaitu menurunya fungsi tubuh, khususnya kemampuan dari sel $\beta$ dalam memproduksi insulin. untuk memetabolisme glukosa (Pangemanan, 2014).

\section{Pola Makan}

Gambaran pola makan pada pasien Diabetes Melitus tipe 2, pada penelitian ini didapatkan sebagian besar pola makan baik 83,3\%. Hal ini menunjukkan bahwa responden Diabetes Melitus tipe 2 di Puskesmas Tarano menjaga pola makan dengan benar sesuai dengan pola makan yang dianjurkan pada responden Diabetes Melitus tipe 2 pada umumnya.

Penyakit Diabetes Melitus banyak dikenal orang sebagai penyakit yang erat kaitannya dengan asupan makanan seperti karbohidrat/ gula, protein, lemak, dan energi yang berlebihan dapat menjadi faktor resiko kejadian Diabetes Melitus. Semakin berlebihan asupan makanan maka semakin besar pula kemungkinan akan memyebabkan Diabetes Melitus (Linder, 2014). Karbohidrat akan dicerna dan diserap dalam bentuk monosakarida, terutama gula. Penyerapan gula menyebabkan terjadinya peningatan kadar glukosa darah dan mendorong peningkatan sekresi hormon insulin untuk mengontrol kadar glukosa darah (Linder, 2014).

Secara teori, tidak terkontrolnya kadar glukosa darah pada responden Diabetes Melitus tipe 2 yang asupan karbohidrat melebihi kebutuhan yang disebabkan oleh tingginya pembentukan glukosa yang bersumber dari karbohidrat dan rendahnya reseptor insulin, seperti yang diungkapkan oleh Edgren, (2012) bahwa jumlah insulin dalam tubuh bisa normal atau lebih, tetapi jumlah reseptor insulin yang terdapat dalam permukaan sel yang masih kurang (PERKENI, 2016).

Penelitian ini sejalan dengan penelitian Fibriana (2005), dalam penelitian menyatakan bahwa tidak ada hubungan yang signifikan antara pola makan dengan kejadian Diabetes Melitus pada pasien, sama dengan penelitian Muliadin (2012) bahwa tidak ada hubungan antara pola makan dengan kejadian Diabetes Melitus tipe 2.

Peneliti menyimpulkan pada penelitian ini bahwa pola makan tidak berpengaruh terhadap skor gula darah pada pasien Diabetes Melitus tipe 2, peneliti menganalisis bahwa pola makan yang baik tanpa di barengi dengan transport glukosa kedalam sel dapat menyebabkan penumpukan glukosa di dalam darah sehingga kadar gula darah pasien Diabetes Melitus menjadi tidak terkontrol. Kurangnya data peneliti mengenai kebutuhan nutrisi yang cukup bagi responden penelitian ini juga menjadi pertimbangan yang menyebabkan pola makan tidak memiliki pengaruh yang signifikan terhadap kadar gula darah pada responden Diabetes Melitus tipe 2 . 
Tabel 2. Distribusi GDS pada kedua kelompok Februari - Maret $2019(\mathrm{n}=24)$

\begin{tabular}{lcccc}
\hline \multicolumn{1}{c}{ Variabel } & Mean & SD & Min-Maks & 95\% CI \\
\hline Kayu manis & & & & \\
sebelum (12) & 302.75 & 43.53 & $243-402$ & $275.09-330.41$ \\
sesudah (12) & 212.58 & 44.18 & $152-317$ & $184.51-240.66$ \\
\hline Jahe merah & & & & \\
sebelum (12) & 305,67 & 56,35 & $230-415$ & $269.86-341.47$ \\
sesudah (12) & 248,67 & 46,41 & $185-341$ & $219.17-278.16$ \\
\hline
\end{tabular}

Sumber : Data primer, 2019

Berdasarkan tabel 2 didapatkan bahwa nilai rata-rata kadar glukosa darah sewaktu sebelum dilakukan intervensi pada kedua kelompok memiliki nilai yang hampir setara, sedangkan nilai gadar glukosa darah sewaktu setelah dilakukan intervensi terdapat pada kelompok kayu manis lebih tinggi dibandingkan dengan kelompok jahe merah.

Tabel 3. Hasil uji normalitas data pada variabel kadar glukosa darah sewaktu pada kelompok kayu manis dan kelompok jahe merah di Puskesmas Tarano Kabupaten Sumbawa NTB Februari-Maret 2019 (n=24)

\begin{tabular}{lcccc}
\hline \multirow{2}{*}{ Kelompok } & \multicolumn{4}{c}{ Pengukuran Kadar Gula Darah Sewaktu } \\
\cline { 2 - 5 } & Mean & SD & n & P Value \\
\hline Kayu manis & 302.75 & 43.53 & 12 & 0.266 \\
Jahe merah & 305.67 & 56.35 & 12 & 0.747 \\
\hline
\end{tabular}

Sumber : Data primer, 2019

Berdasarkan tabel 3 dapat disimpulkan bahwa nilai rata-rata glukosa darah sewaktu pada kedua kelompok normal karena nilai $p$ value $>0,05$ sehingga jenis uji yang digunakan adalah paired t test.

Tabel 4. Perubahan nilai rata-rata penurunan kadar gula darah pasien Diabetes Melitus kelompok kayu manis di Puskesmas Tarano Kabupaten Sumbawa NTB Februari-Maret $2019(n=24)$

\begin{tabular}{cccccc}
\hline Skor gula darah & Mean & SD & SE & CI 95\% & P value \\
\hline Sebelum (12) & 302.75 & 43.53 & 12.5 & \multirow{2}{*}{$88.090-116.244$} & 0,001 \\
Sesudah (12) & 212.58 & 44.18 & 8.61 & & \\
\hline
\end{tabular}

Sumber : Data primer, 2019

Berdasarkan tabel 4 didapatkan bahwa nilai rata-rata kadar glukosa darah sewaktu sesudah dilakukan intervensi mengalami penurunan kadar glukosa darah sewaktu dan dilihat dari nilai $p$ value 0.001 dapat disimpulkan bahwa ada pengaruh seduhan kayu manis terhadap penurunan nilai rata-rata kadar glukosa darah sewaktu pada pasien Diabetes Melitus.

Hasil analisis pada kelompok kayu manis didapatkan bahwa rata-rata skor gula darah sesudah dilakukan pemberian seduhan kayu manis dapat penurunan kadar glukosa darah sewaktu dan nilai $p$ value dapat disimpulkan bahwa ada pengaruh pemberian seduhan kayu manis terhadap penurunan kadar glukosa darah sewaktu, artinya ada perbedaaan skor gula darah sebelum dan sesudah pada kelompok kayu manis. Dalam penelitian ini kelompok kayu manis diberikan perlakuan berupa pemberian seduhan kayu manis dan dilakukan pengukuran pretest dan posttest.

Menurut teori kayu manis mengandung Porifenol yang merupakan doubly linked procyanidin tipe A memiliki aktivitas mirip dengan insulin dan termasuk bagian dari catechin atau epicatechin disebut dengan cinnamomum (Shofiati, 2014). Methylhyroxhalcone polymer (MHCP) yang terkandung dalam kayu manis menunjukan 
peningkatan aktivitas insulin lebih dari 25 kali dibandingkan dengan komponen lain. MHCP menstimulasi peningkatan autofosforilasi dan menurunkan defosforilasi reseptor insulin sehingga menjadi peningkatan sensitivitas insulin, pengambilan glukosa, menghambat aktivitas glikogen sintase-3 $\beta$ dan mengaktifkan glikogen sintase (Medagama, 2015).

Hasil ini sejalan dengan penelitian Darfiani (2015) yang melakukan penelitian dengan cara memberikan seduhan kayu manis sebanyak 7 gram serbuk kayu manis yang diberikan selama 3 hari kepada 20 responden yang dibagi dua kelompok, 10 responden kelompok intervensi dan 10 responden kelompok kontrol, sebelum di intervensi kedua kelompok dilakukan pemeriksaan kadar glukosa darah. Hasil uji statistik t-test pada kelompok kontrol adalah $\mathrm{p}=0,000(\mathrm{p} \leq 0,05)$ dan kelompok intervensi dengan $\mathrm{p}=0,000$ $(\mathrm{p} \leq 0,05)$ artinya ada pengaruh signifikan dari kedua kelompok. Kesimpulan yaitu pemberian bubuk kayu manis dapat menurunkan kadar gula darah pada pasien Diabetes Melitus.

Penelitian lain yang senada dengan penelitian ini adalah Asep Mandani (2016), yang menyatakan pemberian kayu manis dalam menurunkan kadar gula darah pada pasien Diabetes Melitus tipe 2 di bandingkan dengan kunyit dan madu dengan nilai kemaknaan $\mathrm{p}=0,001$.

Diabetes Melitus adalah penyakit metabolik mayoritas sebagai penyakit herediter akibat dari kurangnya insulin karena adanya disfungsi dari sel Beta Pankreas. Pada Diabetes Melitus tipe 2, sel-sel $\beta$ pankreas tidak rusak, walaupun mungkin hanya terdapat sedikit yang normal sehingga masih bisa mensekresi insulin, tetapi dalam jumlah kecil sehingga tidak cukup untuk memenuhi kebutuhan tubuh.

Berdasarkan hasil analisa fakta dan teori diatas peneliti sepakat bahwa pemberian seduhan kayu manis dapat menurunkan kadar glukosa darah pada pasien Diabetes Melitus karena kandungan yang terdapat didalam kayu manis itu sendiri. Pada saat seseorang mengkomsumsi seduhan kayu manis Porifenol akan membantu insulin untuk memasukan gula darah yang menumpuk di dalam pembuluh darah sehingga dapat masuk ke dalam sel sehingga proses metabolisme tubuh terpenuhi dan dapat terdedeksi dengan cara pengukuran gula darah sewaktu.

Tabel 5. Perubahan nilai rata-rata penurunan kadar gula darah pasien Diabetes Melitus kelompok jahe merah di Di Puskesmas Tarano Kabupaten Sumbawa NTB Februari-Maret $2019(\mathrm{n}=12)$

\begin{tabular}{cccccc}
\hline Skor gula darah & Mean & SD & SE & CI 95\% & P value \\
\hline Sebelum (12) & 305.67 & 56.35 & 16.26 & \multirow{2}{*}{$48.881-65.119$} & 0,001 \\
Sesudah (12) & 248.67 & 46.41 & 13.4 & & \\
\hline
\end{tabular}

Sumber : Data primer, 2019

Berdasarkan tabel 5 didapatkan bahwa nilai rata-rata kadar glukosa darah sewaktu sesudah dilakukan intervensi mengalami penurunan kadar glukosa darah sewaktu dan dilihat dari nilai $p$ value 0.001 dapat disimpulkan bahwa ada pengaruh seduhan jahe merah terhadap penurunan nilai rata-rata kadar glukosa darah sewaktu pada pasien Diabetes Melitus.

Hasil analisis pada kelompok jahe merah didapatkan bahwa rata-rata skor gula darah sesudah dilakukan intervensi jahe merah mengalami penuruanan kadar glukosa darah sewaktu dan nilai $p$ value dapat disimpulkan bahwa ada pengaruh pemberian jahe merah terhadap kadar glukosa darah sewaktu, artinya ada perbedaaan skor gula darah sebelum dan sesudah pada kelompok jahe merah. Dalam penelitian ini kelompok jahe 
merah diberikan perlakuan berupa pemberian seduhan jahe merah dan dilakukan pengukuran pretest dan posttest.

Menurut teori (Wahclos, 2017) jahe merah mengandung gingerol merupakan kandungan yang aktif dalam rimpang jahe dan dapat meningkatkan penyerapan glukosa darah ke dalam sel otot tanpa memerlukan insulin, jahe merah dapat mengendalikan gula darah pada pasien Diabetes Melitus. Rimpang jahe merah berinteraski dengan reseptor serotonin yang berefek meningkatkan sekresi insulin dan membantu menurunkan kadar gulah darah dengan cara masuk kedalam sel tubuh. Pengobatan herbal menggunakan rimpang jahe merah dapat membuat $35 \%$ penurunan kadar glukosa darah dan 10\% peningkatan insulin dalam plasma darah. Jahe dapat meningkatkan sensitivitas insulin serta obat yang digunakan untu meningkatkan mengobati diabetes (Wahclos, 2017).

Hasil ini sejalan dengan penelitian Arman (2016) yang melakukan penelitian dengan cara memberikan serbuk kering jahe merah sedangan dosis 3 gram srbuk kering jahe merah perhari yang diberikan selama 3 hari kepada 34 responden yang dibagi dua kelompok, 17 responden kelompok intervensi dan 17 responden kelompok kontrol, sebelum di intervensi kedua kelompok dilakukan pemeriksaan kadar glukosa darah. Perubahan kadar gula darah di uji dengan analisis kovarian (ANCOVA) dengan nilai signifikansi $\mathrm{p}<0,05$. Kesimpulan penelitian adalah sebuk kering jahe merah dapat menurunkan glukosa darah puasa dengan nilai signifikansi $(p=0,031)$ sedangan serbuk kering jahe merah tidak berpengaruh terhadap Glukosa darah dengan nilai signifikansi $(\mathrm{p}=0,514)$.

Berdasarkan hasil analisa fakta dan teori diatas peneliti sepakat bahwa pemberian jahe merah dapat menurunkan kadar glukosa darah pada pasien Diabetes Melitus karena kandungan yang terdapat didalam jahe merah itu sendiri. Pada saat seseorang mengkomsumsi seduhan jahe merah gingerol reseptor serotonin yang berefek meningkatkan sekresi insulin dan membantu menurunkan kadar gulah darah dengan cara masuk kedalam sel tubuh.

Tabel 6. Perubahan selisih rata-rata penurunan kadar gula darah pasien Diabetes Melitus kelompok kayu manis dan jahe merah di Puskesmas Tarano Kabupaten Sumbawa NTB Februari-Maret 2019 (n=24)

\begin{tabular}{lcccc}
\hline \multirow{2}{*}{ Variabel } & \multicolumn{4}{c}{ Pengukuran Kadar Gula Darah Sewaktu } \\
\cline { 2 - 5 } & Nilai selisih & SD & SE & P value \\
\hline Kayu manis & 90.17 & 21.31 & 6.15 & \\
Jahe merah & 57 & 12.78 & 3.68 & 0.001 \\
Selisih Mean & & 33.17 & & \\
\hline
\end{tabular}

Sumber : Data primer, 2019

Berdasarkan tabel 6 didapatkan pada kedua kelompok ada perbedaan selisih ratarata glukosa darah setelah diberikan kayu manis dan jahe merah. Pada kelompok kayu manis memiliki selisih rata-rata kadar glukosa darah lebih tinggi dari pada kelompok jahe merah dan dilihat dari nilai $p$ value 0.001 dapat disimpulkan bahwa ada perbedaan selisih mean yang bermakna pada kelompok kayu manis dan jahe merah terhadap nilai kadar glukosa darah sewaktu pada pasien Diabetes Melitus.

Analisis dari kedua kelompok kayu manis dan jahe merah didapatkan skor dimasing-masing kelompok intervensi, pada kelompok kayu manis didapatkan nilai selisih rata-rata sedangkan pada kelompok jahe merah didapatkan nilai selisih rata-rata dan dapatkan nilai P Value 0.001. Dari hasil analisis diatas bahwa pemberian seduhan 
kayu manis dan jahe merah sama-sama menurunkan kadar glukosa darah, tetapi dilihat dari rata-rata pemberian seduhan kayu manis lebih banyak menurunkan kadar glukosa darah pada pasien Diabetes Melitus tipe 2, dapat di lihat dari nilai rata-rata penurunan kadar glukosa darah pada masing-masing kelompok. Pada kelompok kayu manis 90.17 $\mathrm{mg} / \mathrm{dL}$ penurunan kadar glukosa darah setelah diberikan intervensi sedangkan pada kelompok jahe merah didapatkan $57 \mathrm{mg} / \mathrm{dL}$ penuruan kadar glukosa darah setelah diberikan intervensi. Pada kelompok kayu manis memiliki selisih rata-rata nilai kadar glukosa darah lebih tinggi dari pada kelompok jahe merah yaitu sebesar $33.17 \mathrm{mg} / \mathrm{dL}$.

Berdasarkan selisih rata-rata yang didapatkan antara kelompok kayu manin dan jahe merah menunjukkan bahwa selisih penurunan kadar glukosa darah pada kelompok kayu manis lebih besar dibandingkan dengan jahe merah. Kadar glukosa darah dapat menurun apabila glukosa dalam darah diubah menjadi energy, sehingga tidak menumpuk dialiran darah yang membuat kadar glukosa darah tinggi. Pada penelitian ini kedua kelompok tersebut sama-sama berpengaruh dalam menurunkan kadar glukosa darah pada pasien Diabetes Melitus tipe 2.

Menurut teori (Black \& Hawks, 2014) pasien Diabetes Melitus darah pada tubuh pasien akan menjadi kental dan di penuhi dengan glukosa. Pasokan glukosa ini tidak dapat dihantarkan kedalam sel oleh insulin dikarenakan ketidakmampuan tubuh untuk memproduksi insulin. Dikarenakan hal tersebut insulin hanya bisa mengangkut sekitar $25 \%$ glukosa kedalam sel dari jumlah total kebutuhan sel di dalam tubuh untuk proses metabolisme didalam tubuh. Hal ini menyebabkan pengukuran kadar gula darah pada pasien Diabetes Melitus mejadi tinggi. Kadar glukosa darah pada pasien Diabetes Melitus tidak dapat menurun apabila tidak dilakukan tindakan untuk menurunkannya baik dengan cara farmakologis dan non farmakologis (Black \& Hawks, 2014).

Serbuk kayu manis dapat menghasilkan minyak esensial yang dapat membantu menurunkan kadar glukosa darah dengan cara meniru efek insulin dan meningkatkan pemindahan glukosa kedalam sel, sehingga hal ini dapat membantu pengingkatan sensitivitas insulin dan membuat insulin lebih efesien dalam memindahkan glukosa kedalam sel sehingga glukosa darah terkontrol dan diberikan setelah makan karena kayu manis dapat memperhambat enzim pencernaan yang memecah karbohidrat diusus (Rismunandar, 2014). Sedangkan pemberian air rebusan kayu manis diteliti oleh Amri (2014) di laboratorium Universitas Riau didapatkan hasil bahwa ada pengaruh pemberian air rebusan kayu manis terhadap kadar glukosa darah pada pasien Diabetes Melitus.

\section{SIMPULAN}

Karakteristik dari 24 responden, meliputi : rata-rata usia 36 sampai dengan $>66$ tahun, dan hampir semua responden menyatakan pola makan baik. Ada perbedaan nilai ratarata glukosa darah setelah dilakukan intervensi pada kelompok kayu manis. Dan ada perbedaan nilai rata-rata glukosa darah setelah dilakukan intervensi pada kelompok jahe merah. Maka dapat ditarik kesimpulan bahwa rerata glukosa darah pada kelompok kedua kelompok kayu manis dan jahe merah sama-sama dapat menurunkan kadar glukosa darah setelah diberikan intervensi, tetapi dapat dilihat dari nilai selisih rata-rata pada kelompok kayu manis memiliki selisih rata-rata nilai kadar glukosa darah lebih tinggi dari pada kelompok jahe merah. 


\section{SARAN}

Bagi Pelayanan Keperawatan, Perawat dapat mengembangkan program pelatihan terapi dan sosialisasi terhadap terapi herbal agar perawat dapat mengaplikasikan terapi herbal dalam memberikan asuhan keperawatan pada pasien Diabetes Melitus tipe 2 dalam menurunkan glukosa darah dan mengembangkan kebijakan Puskesmas tentang asuhan keperawatan herbal pada pasien Diabetes Melitus tipe 2 yang mengalami kadar glukosa darah sewaktu yang tinggi dengan mempertimbangkan hasil penelitian ini sebagai salah satu acuan. Bagi Pendidikan Keperawatan, Penelitian ini diharapkan bisa dijadikan tambahan ilmu pengetahuan keperawatan khususnya yang berkaitan dengan intervensi keperawatan dalam terapi non farmakologis. Membangun program kerjasama dengan lahan pelayanan kesehatan dalam rangka mengembangkan praktik keperawatan berbasis terapi komplementer, salah satunya adalah terapi herbal. Melakukan penyebarluasan informasi dan pengetahuan tentang terapi komplementer seperti herbal melalui seminarseminar dan workshop keperawatan. Bagi peneliti selanjutnya, Bagi peneliti selanjutnya diharapkan bisa berfokus pada perubahan kadar glukosa darah dan perubahan $\mathrm{HbA1c}$ serta di lihat faktor counfonding pada penderita Diabetes Melitus.

\section{DAFTAR PUSTAKA}

Agoes , \& Hall, J . (2015). Buku Ajar Fisiologi Kedokteran \& obat farmakologi pada sistem endokrin (9th ed.). Jakarta: EGC.

American Diabetes Association, ADA. (2014). Diabetes Care Standards of Medical Care In Diabetes. The Journal of Clinical and Applied Research and Education, 41 (1). https://doi.org/10.2337/dc18-Sint01

Amri. (2014). pengaruh terapi herbal Dengan Kadar Gula Darah Pada Karyawan Di Rs Tingkat Iv. Efektor Issn. 0854-1922, 01, 65-72.

Apriyanti, M. (2015). Meracik Sendiri Obat dalam menurunkan kadar gula darah \& Menu Sehat Bagi Penderita Diabetes Melitus. Yogyakarta: Pustaka Baru Press.

Arman Eliza. (2016). pengaruh terapi jahe merah Dengan Kadar Gula Darah Pada Penderita Diabetes Melitus Di Rs Tingkat Iv. Efektor Issn. 0854-1922, 01, 6572.

Asep mandani (2016). Pengaruh pemberian kayu manis terhadap penurunan kadar glukosa darah (9th ed.). Jakarta: EGC.

Black, J. M., \& Hawks, J. H. (2014). Keperawatan Medikal Bedah: Keperawatan Klinis untuk Hasil yang di Harapkan (8th ed.). Jakarta: EGC.

Bobby, A (2015) Effec of cinnamomun as an Therapy for blood glucose Diabetes Mellitus: A Randomized Controlled Trial. Medical Acupuncture, 6(26), 341345. https://doi.org/DOI:10.1089/acu.2014.1058

Dinkes kab Sumbawa. (2017). angka kejadian Diabetes Melitus. French. Retrieved fromhttp://www.who.int/about/licensing/\%5Cnhttp://apps.who.int/iris/bitstrea $\mathrm{m} / 10665 / 204871 / 1 / 9789241565257$ eng.pdf

Darfiani. (2015). Pengaruh Pemberian Terapi Jahe Merah Terhadap Penurunan Kadar Glukosa Darah. (9th ed.). Jakarta: EGC.

Deshpande, Hayes \& schootman. (2012). Overview of complementary and alternative medicine and diabetes. Practical Diabetes, 31(9), 381-386. https://doi.org/10.1002/pdi.1908

Edgren. (2012). Buku Ajar Fisiologi Kedokteran \& obat farmakologi pada sistem endokrin (9th ed.). Jakarta: EGC. 
Farry, K. (2014). Effectiveness of cinnamomun as an Adjunctive Therapy for Diabetes Mellitus: A Randomized Controlled Trial. Medical Acupuncture, 6(26), 341345. https://doi.org/DOI:10.1089/acu.2014.1058

Fibriana. (2005). Pengaruh Pemberian Terapi Jahe Merah Terhadap Penurunan Kadar Glukosa darah (9th ed.). Jakarta: EGC.

International Diabetes Federation. (2017). Diabetes Atlas. (S. Karuranga, J. da R. Fernandes, Y. Huang, \& B. Malanda, Eds.). International Diabetes Federation (8th ed., Vol. 8). https://doi.org/10.1017/CBO9781107415324.004

Linder. (2014). Buku Ajar Fisiologi Kedokteran \& Obat Farmakologi Pada Sistem Endokrin (9th ed.). Jakarta: EGC.

Medagama, R. F., Ropi, H., \& Kurniawan, T. (2015). Pengaruh Terapi Komplementer Terhadap Kadar Gula Darah Pada Pasien Diabetes Melitus Tipe II.

Muliadin. (2012). Faktor yang Berhubungan dengan Pengendalian Gula Darah pada Penderita Diabetes Mellitus di Perkotaan Indonesia. Majalah Kedokteran Indonesia, 59(9).

Nursalam. (2015). Metodologi Penelitian Ilmu Keperawatan (4th ed.). Jakarta: Salemba Medika.

Pangemana. N. (2014). Pola Konsumsi Makanan Tradisional Bali sebagai Faktor Risiko Diabetes Melitus Tipe 2di Tabanan. Jurnal Skala Husada, 6(1), 75-81.

PERKENI. (2015). Konsensus Pengendalian dan Pencegahan Diabetes Melitus Tipe 2 di Indonesia 2015. Perkeni. https://doi.org/10.1017/CBO9781107415324.004

Profil Kesehatan NTB. (2018). Angka Kejadian Diabetes Melitus di NTB. French. Retrieved fromhttp://www.who.int/about/licensing/\%5Cnhttp://apps.who.int/iris/bitstrea $\mathrm{m} / 10665 / 204871 / 1 / 9789241565257$ eng.pdf

Riset Kesehatan Dasar. (2018). Badan Penelitian dan Pengembangan Kesehatan Kementerian Kesehatan RI, 9 dan 121.

Riskesdas. (2018). Angka Kejadian 10 Penyakit Di Indonesia. French. Retrieved fromhttp://www.who.int/about/licensing/\%5Cnhttp://apps.who.int/iris/bitstrea $\mathrm{m} / 10665 / 204871 / 1 / 9789241565257$ eng.pdf

Rismunandar. (2014). Pengaruh Terapi Herbal Dengan Kadar Gula Darah Pada Karyawan Di RS Tingkat IV. Efektor Issn. 0854-1922, 01, 65-72.

Sarwono, A. (2014). Dasar-Dasar Endokrinologi (1st ed.). Jakarta: Rayyana Komnikasindo.

Shofiati, A. (2014). Pengaruh Pemberian Jahe Merah Dengan Kadar Gula Darah Pada Penderita Diabetes Melitus Tipe 2 Di Rumah Sakit Umum Daerah padang, XXXIII(2), 81-87. https://doi.org/10.1007/s13398-014-0173-7.2

Sujaya, I. N. (2009). Pola Konsumsi Makanan Tradisional Bali sebagai Faktor Risiko Diabetes Melitus Tipe 2di Tabanan. Jurnal Skala Husada, 6 (1), 75-81.

Sunjoyo, A. W., Setiati, S., Alwi, I., Setiyohadi, B., \& Syam, A. F. (2014). Buku Ajar Ilmu Penyakit Dalam (Vol. 1). Jakarta: Interna Publishing.

Suyono, S. (2014). Terapi Alternatif Pada Pasien Diabetes Melitus (5th ed.). Jakarta: Sagung Seto.

Wahclos, (2017). Pola Konsumsi Makanan Tradisional Bali sebagai Faktor Risiko Diabetes Melitus Tipe 2di Tabanan. Jurnal Skala Husada, 6(1), 75-81.

Wulandari. (2015). Nursing Research Methods and Critical Appraisal For EvidenceBased Practice. St. Louis, Missouri: Mosby Elsevier 
World Health Organization. (2016b). Global Report on Diabetes. French. Retrieved fromhttp://www.who.int/about/licensing/\%5Cnhttp://apps.who.int/iris/bitstrea m/10665/204871/1/9789241565257_eng. 